\title{
The Mufti Against the Governor: a Short Confrontation, 1790-1791
}

\author{
Andrey S. Ryazhev \\ Kalmyk scientific center of the Russian Academy of Sciences. Elista, Russia. \\ Email: ryazhevas[at]kigiran.com
}

\begin{abstract}
The article focuses on the religious policy of the Russian Empire in the early modern period. The aim of the research is to study the mutual relations of the governor A.A. von Peutling and Muhammedjan Khuseinov, the first mufti of Russia and the head of the Orenburg Mohammedan Spiritual Assembly at the beginning of 1790s, which influenced the religious situation on the southern and south-eastern outskirts of Russia. The base of the study is the official correspondence of A.A. von Peutling that described the place of Muslim religious institutions in the Russian system of government. The research methodology is defined by the main interpretations of the Russian religious policy, found in the literature on Islam in Russia. The author identifies the reasons and causes of the official and interpersonal conflict between the governor and the mufti as well as emphasizes the significant independence of the mufti at the beginning of 1790s on the steppe frontier. It is revealed that at that time the mufti was a more significant figure than the governor from the viewpoint of the supreme power. The author concludes that, in general, the religious policy of the Russian Empire during the examined period was invariant, but the regional specifics and subjective factors determined significant differences in its implementation in the South-East compared to the Crimea (then) and the North Caucasus (later).
\end{abstract}

The article is addressed to experts in the fields of history of religion and politics of Russia in the 18th century, religious scholars, students, masters and postgraduates of the relevant profile.

\section{Keywords}

The Russian Empire; Early Modern Period; Empress Catherine II; the Southern and South-Eastern Outskirts of Russia; Governor A.A. von Peutling; Mufti Muhammedjan Khuseinov; Qazakh People; Muslim; Orenburg Mohammedan (Muslim) Spiritual Assembly; Religious Policy 


\section{Муфтий против губернатора: короткое противостояние (1790-1791 гг.)}

\section{Ряжев Андрей Сергеевич}

Калмыцкий научный центр Российской академии наук. Элиста, Россия.

Email: ryazhevas[at]kigiran.com

\section{Аннотация}

Статья посвящена вероисповедной политике Российской империи в раннее Новое время. Цель исследования - изучить взаимоотношения начала 1790-х гг. между наместником А.А. фон Пеутлингом и М. Хусейновым, первым российским муфтием и главой Оренбургского магометанского духовного собрания, влиявшие на вероисповедную обстановку южных и юго-восточных окраин Российской империи. В основе исследования лежит служебная переписка губернатора Пеутлинга, характеризующая место мусульманских духовных институтов в российской системе власти. Методологию предлагаемой работы определил структурнофункциональный подход к системе государственных органов России. Автор выявляет основные трактовки вероисповедной политики в отношении ислама на границах России, встречающиеся в современной литературе, характеризует причины и ход служебного и межличностного конфликта между губернатором и муфтием, устанавливает различия в понимании обоими роли мусульманских институтов и муфтия в окраинной политике России, её взаимоотношениях с пограничными кочевниками-казахами, подчеркивает значительную самостоятельность муфтия в событиях начала 1790-х гг. на степной границе. Доказывается, что для верховной власти муфтий на тот момент был более значимой фигурой, нежели губернатор. Делается вывод, что в целом вероисповедная политика Российской империи в изучаемое время была инвариантной, однако региональная специфика и субъективный фактор определяли существенные различия в её осуществлении на юго-востоке по сравнению с Крымом (тогда) и Северным Кавказом (позже).

Статья адресована специалистам по истории религии и политики России в XVIII в., религиоведам, аспирантам, магистрантам, студентам соответствующего профиля.

\section{Ключевые слова}

Российская империя; раннее Новое время; Екатерина II; южные и юго-восточные окраины России; наместник (губернатор) А.А. фон Пеутлинг; муфтий М. Хусейнов; казахи; ислам; Оренбургское магометанское духовное собрание; вероисповедная политика

Это произведение доступно по лицензии Creative Commons “Attribution” («Атрибуция») 4.0 Всемирная 


\section{Введение}

Вероисповедная политика российской монархии раннего Нового времени - актуальный вопрос историографии политической истории XVIII в. (Ряжев, 2006, с. 84-86). Одним из принципиально важных аспектов этого вопроса выступают властные взаимоотношения, в том числе коммуникация акторов подобных взаимоотношений на различных уровнях - центральном, региональном, местном.

В этой связи представляют интерес коллизии между двумя должностными лицами, во многом определявшими курс государства на юго-восточной окраине в первой половине 1790-х гг. Одним из них был уфимский наместник (генерал-губернатор) генерал-майор барон А.А. фон Пеутлинг, другой - глава Духовного собрания мусульман муфтий М. Хусейнов. Известно, что данные коллизии привели к служебному и личному конфликту и закончились в конечном итоге вынужденной отставкой сановника. Подобный эпизод был единственным случаем такого рода в более чем столетней истории взаимоотношений светских и мусульманских начальников Российской империи. Его необходимо изучить, что и составляет задачу предлагаемой работы.

Обозначенная тема исследования предполагает анализ следующих проблем: формирование противоречий между губернатором и муфтием, развитие служебного и межличностного конфликта и, наконец, причины, по которым он получил вполне определённое разрешение.

\section{Материалы и методы}

Источником служит служебная переписка наместника за 1790-1793 гг., выявленная в Российском государственном архиве древних актов (РГАДА, ф. 16, оп. 1, д. 991, ч. 1-4). Массив бумаг состоит из донесений императрице Екатерине II (в основном), дипломату А.А. Безбородко и генерал-прокурору А.Н. Самойлову. Предмет переписки - управление и безопасность подведомственных сановнику территорий юго-востока Европейской России (Уфимской и Оренбургской губерний) в указанные годы. Основными вопросами, обсуждавшимися в ней, были военно-политическая обстановка на границе и ситуация в казахском Младшем жузе, где развивалось движение старшины Срыма Датова (Дат-улы), направленное против ханской власти и порождавшее нестабильность во взаимоотношениях российских властей и казахской степи. Переписка характеризует разногласия по поводу пограничного урегулирования между светским и мусульманским духовным начальниками, раскрывает причины и развитие конфликта между ними. Вместе с тем она даёт представление о подходах должностных лиц и учреждений к пограничному урегулированию и взаимоотношениям со степняками в целом, о роли ислама в казахской степи изучаемого времени, и её значение трудно переоценить. 
Для всестороннего изучения затронутой темы привлечены опубликованные документы, характеризующие общественный уклад жизни и обусловленную им деятельность мусульманского духовенства у казахов (Материалы по истории Казахской ССР, 1940; Материалы по истории политического строя Казахстана, 1960).

Методология исследования определена структурно-функциональным подходом к системе государственных органов России. В его рамках, прежде всего, обеспечено выявление принципов и порядка взаимодействия в центре и на окраинах светских и духовных институций, причём независимо от конфессиональной принадлежности последних. Применяемый научный инструментарий охватил также методы анализа источников и обобщения полученных данных, способствовавшие повышению информативности документов и установлению смысловых и содержательных связей между ними. Для обобщения информации применён проблемно-хронологический метод. На его основе прослежено развитие обозначенной конфликтной ситуации и выявлена её политическая основа.

\section{Обсуждение}

Обстановка конца 80-90-х гг. XVIII в. на российских юго-восточных границах и в казахских кочевьях, особенно в Младшем жузе, освещена в литературе о мусульманском духовенстве на русской службе и Оренбургском магометанском духовном собрании (ОМДС), однако с преимущественным вниманием к событиям XIX в. (Азаматов, 1999; Горбунова, 2008; Ковальская, Любичанковский, 2017; Лысенко, 2010; Любичанковский, 2016; Махмутов, 2017; Почекаев, 2014; Ремнев, 2006; Речкина, 2006; Франк, 1993; Шаблей, 2008).

Также прослежены связи между Османской империей и Бухарским эмиратом, грозившие в последней четверти XVIII в. осложнениями на юговосточных российских рубежах (Васильев, 2014, с. 101-110), деятельность османских сторонников на российских окраинах (Смирнов, 1950, с. 19-39; Конкин, 2020, с. 134-138).

Отведено в историографии место и деятельности М. Хусейнова, первого муфтия ОМДС. В частности, рассмотрена его степная командировка весной 1790 г., издан путевой журнал - ценный источник по истории екатерининской религиозной политики (Вяткин, 1939; Мубаракзянов, 2011; Ряжев, 2004; Султангалиева, 2009, 2012).

Необходимо также указать на исследования российского курса в отношении степи, где затронуты дипломатические и религиозные аспекты этого курса (Вяткин, 1947; Избасарова, 2015; . История Казахской ССР, 1979; Лапин, 2012; Султангалиева, 2011; Шаблей, 2010; Campbell, 2017).

В контексте изучаемой проблематики оправданными представляются крымские параллели, с учётом которых можно оценить вариативность стра- 
тегии властей в последние десятилетия XVIII в. на имперском фронтире (Хайрединова, 2016, с. 66-68; Проблемы интеграции Крыма в состав России, 2017, с. 29, 104, 116-119, 289; Прохоров, 2020, с. 179-185).

\section{Формирование противоречий}

Екатерина II назначила М. Хусейнова главой Духовного собрания мусульман в 1788 г. Его рекомендателем перед монархиней явился предшественник А.А. Пеутлинга губернатор О.А. Игельстром. В дальнейшем муфтий выступал креатурой последнего, во многом разделяя его воззрения на пограничное урегулирование и поддерживая соответствующие начинания. В своё время, до назначения в ОМДС и в бытность первым (главным) ахуном Оренбургского края - начальником над мусульманским духовенством, состоявшим на степной российской службе, муфтий вошёл в клинч с начальством Оренбургской Пограничных дел экспедиции и оренбургскими властями в целом. Однако поддержка О.А. Игельстрома помогла муфтию удержаться на месте и даже продвинуться по службе. Несмотря на противостояние с региональными властями, связи М. Хусейнова с казахской верхушкой, знание им традиций и обычаев степной и, шире, азиатской дипломатии, знаки благоволения, оказанные ему императрицей по протекции О.А. Игельстрома, делали муфтия важным актором восточной политики государства.

В том же 1788 г. О.А. Игельстром получил новое назначение. Политическая обстановка того времени на российских юго-восточных границах представлялась предельно сложной. Россия вела две войны - против Турции и Швеции, для Срыма Датова и его ближайшего окружения становились актуальными антироссийские религиозные призывы, формировавшиеся духовенством среднеазиатских государств под прямым воздействием османской дипломатии. Соответственно, у российских властей возникали опасения на предмет пограничной религиозной войны, способной в интересах Турции создать угрозу российским интересам в Северном Прикаспии и на Южном Урале.

О.А. Игельстрома, отбывшего к театру войны со Швецией, заменил А.А. Пеутлинг, длительное время значившийся только исполняющим обязанности (формально наместником оставался его предшественник) и посему чувствовавший себя на посту не вполне уверенно. К тому же он и в сложившейся ситуации ориентировался хуже, нежели О.А. Игельстром. Совокупность подобных факторов способствовала росту самостоятельности муфтия и в казахских степных делах, и в делах религии.

Вскоре возник повод эту самостоятельность проявить. В начале 1790 г. властям стало известно о посланиях шейха Мансура, направленных российским мусульманам для побуждения их к войне против России, в частности, в Крым. Стало известно о появлении таких писем и в казахской степи. 
Среди документов А.А. Пеутлинга сохранились два письма Мансура в русском переводе (оригиналы писем не обнаружены). Авторство отражено в обоих письмах - в первом случае налицо этикетная формула, во втором фрагмент интитуляции. О самом шейхе, выдававшем себя за преемника пророка Мохаммеда, с середины 1780-х гг. было хорошо известно (Елисеева, 2005, с. 377-379). Посему и губернатор, и его степная агентура в принадлежности посланий горскому вождю не сомневались.

Письма являются религиозно-политическими воззваниями. Их религиозная сторона, насколько можно судить по изученным переводам, проста: соединение основных принципов ислама с житейским морализаторством. Политическая же сторона выглядела прагматичной, отвечавшей турецким видам: Мансур призывал к разрыву отношений казахов с Россией, общей борьбе и прежде всего - нападению казахов на Астрахань.

Датировка обоих писем приблизительна: переводы ушли в столицу с донесением А.А. Пеутлинга от 13 марта 1790 г. на имя Екатерины II. Соответственно, к этому времени сановник, располагая письмами, сделал прогноз о последствиях их хождения в степи.

Губернатора прежде всего встревожила возможность того, что Срым выступит в координации с чеченским лидером. Посему он немедленно постарался выяснить через доверенных людей в степи, получены ли письма и намерены ли адресаты впредь сноситься с шейхом. Первые донесения на сей счёт были для губернатора обнадёживающими, однако неопределёнными, сановник же нуждался в точных сведениях. В этой связи он предписал М. Хусейнову немедленно выехать в Степь, внеся в инструкцию муфтия специальный пункт:

«Известный мятежник и лжепророк Ших Мансур также почасту старается пересылать к ним возмутителныя писмы. Не трудно ли Вам будет вселить в киргизских старшин истинных понятии о сем... обманщике и соблазнителе, доказав им, что все его внушения прямо противны закону [религии]... яко... противныя верноподданнической их должности» (РГАДА, ф. 16, оп. 1, д. 991, ч. 1, л. 53).

Источники свидетельствуют, что сведения о письмах очень тревожили губернатора, посему приказ о выезде муфтия был срочным, а приготовления к выезду велись спешно (РГАДА, ф. 16, оп. 1, д. 991, ч. 1, л. 31 и об., 50, 58 и об., 62 об., 66-68 об., 249 об., 256-258 об.). Перипетии муфтиева путешествия в апреле - мае 1790 г. подробно изложены в его путевом журнале и донесениях губернатора императрице. М. Хусейнов сделал все, чтобы преподнести поездку как удачную. В доказательство он ссылался на клятвенное обещание Срыма Датова, что к Мансуру у того «вероятия не будет» (РГАДА, ф. 16, оп. 1, д. 991, ч. 1, л. 289). Губернатор сразу по окончании поездки склонялся к поддержке подобной оценки. А.А. Пеутлинг еще более укреплялся в ней на фоне сведений лета - осени об альянсе Османской империи и Бухары, из-под влияния которого Срым представлялся теперь выведенным. 
Однако далеко не все разделяли оценки итогов муфтиевой поездки, особенно сразу по ее окончании. О недовольстве муфтием заявили российские должностные лица. Так, глава Оренбургской Пограничных дел экспедиции и обер-комендант Оренбурга генерал-майор Я.М. Зембулатов, атаман Уральского казачьего войска подполковник Д.Д. Донсков протестовали против рекомендаций муфтия, сделанных после поездки и означавших, по мнению командиров, что тот решительно принял сторону казахов в их столкновениях с казаками-уральцами (РГАДА, ф. 16, оп. 1, д. 991, ч. 1, л. 326 об. - 327).

Кроме того, на муфтия поступили доносы, из которых следовало, что его успехи на переговорах весной 1790 г. отнюдь не бесспорны. В частности, мулла С. Бекмухаметев убеждал А.А. Пеутлинга, что Срым не доверял и не доверяет муфтию. Батыр толковал, «якобы муфтий едет к ним не для чего иного, как их обманывать, но что бы он ни внушал, русские с ними не мирны, но в военном положении находятся», а посему, добавлял мулла, клятвы и самого Срыма притворны (РГАДА, ф. 16, оп. 1, д. 991, ч. 1, л. 252 об.).

Имели место и другие доносы мусульман - духовенства и служилых людей, в которых муфтий обвинялся в претензиях на исключительное посредничество между императрицей и казахами и раздаче от ее имени гарантий, которые, по мнению доносителей, лишь спровоцируют кочевников на более злостные проявления нелояльности Поступавшие к губернатору бумаги подобного содержания вынудили того в короткий срок пересмотреть позицию в отношении итогов муфтиевой поездки.

Кроме того, степной вояж муфтия выявил и разницу в подходах обоих к пограничному урегулированию: если муфтий, следуя планам О.А. Игельстрома, полагал нужным упразднить ханскую власть и децентрализовать управление, введя в него родовую верхушку, то А.А. Пеутлинг - восстановить хана и опереться на аристократов-султанов. В этой связи глава ОМДС поддерживал старшин и Срыма как главного среди них, представляя их опорой российской власти в Степи, тогда как для губернатора они в свете поступивших доносов выглядели людьми сомнительными и отнюдь не заслуживающими доверия свыше.

Наконец, оба по-разному смотрели на место самого муфтия в системе пограничной дипломатии: для губернатора муфтий был его порученцем по делам ислама, пусть и более статусным, нежели обычный, рядовой мулла. Муфтий же в условиях известного вакуума региональной власти полагал себя фигурой самостоятельной, в известной мере, равновеликой новому губернатору. Это и стало питательной почвой конфликта, разросшегося в течение последующего полугодия. 


\section{Развитие конфликта}

Перейдём к рассмотрению конфликта. Отправной точкой в его развитии стал перерасход муфтием командировочных средств, выданных на степную поездку (РГАДА, ф. 16, оп. 1, д. 991, ч. 1, л. 256-258). Разногласия по этому поводу возникали и накануне поездки, в апреле. Теперь же наместнику пришлось по данному поводу объясняться с верховной властью, и на это были свои причины.

Смета поездки включала в себя ряд статей на «путевые издержки и на свиту двести рублей, да на дарение киргизцов от его имяни по записке его лекарствами и разными пряными зельями сто пятьдесят рублей» (РГАДА, ф. 16, оп. 1, д. 991, ч. 1, л. 256). Однако муфтий допустил бо́льшие издержки, затем покрыл их займом на стороне, а для расчёта с кредиторами по возвращении просил компенсацию из государственных средств.

Вольность в обращении с казёнными деньгами была неприятна губернатору, но ещё более неприятными оказались действия, её вызвавшие, ибо муфтий вдруг решил одаривать казахов не от себя, а в знак Высочайшего к ним благоволения. Поэтому он, будучи уже в пути, подал бумагу обер-коменданту Оренбурга о выдаче 1650 руб. на новые покупки (РГАДА, ф. 16, оп. 1, д. 991, ч. 1, л. 256).

Перед императрицей губернатор всячески оправдывался: муфтию неоднократно были даны указания тратить командировочную сумму только на дорожные расходы и мелкие подарки. «При чем же дал ему на замечание, добавлял А.А. Пеутлинг, - что таковые награждения, будучи же яко от лица Вашего, никто из верноподданных Ваших без точного Вашего Величества повеления давать не может...» (РГАДА, ф. 16, оп. 1, д. 991, ч. 1, л. 256). К тому же награждать, полагал губернатор, на тот момент было некого: после «недавних замешательств» на границе сначала следовало проверить, кто из старшин сохранил лояльность. Наместник указал муфтию не спешить с наградами,

«но когда он преуспеет в увещевании их, и благонадежные будут определены, то может о них сообщить через меня к Е.И.В.» (РГАДА, ф. 16, оп. 1, д. 991, ч. 1, л. 257).

Но муфтий в ходе поездки, как выяснилось тогда же, поступил по-своему. А.А. Пеутлинг давал на сей счёт следующий комментарий:

«Известил он меня из Уральска, что за неполучением от меня денег на нужные киргис-кайсакам подарки принужденным он нашелся взять на кредит на семьсот рублев товаров, которые денги я б благоволил приказать заплатить. Я на сие писмо с сильнейшими еще убеждениями повторил ему, чтоб удержался раздачею тех вещей от лица Вашего, разве что от себя хочет дарить киргизцов, но тогда кроме выданных ему ста пятидесяти рублев уже более денег требовать не может. Не взирая на все сие, при возвращении своем подал он ко мне при писме расход деньгам, в котором показывает, что на подарки киргизским старшинам в знак Высочайшего Вашего к ним благоволения и на угождение их употреблено им сверх выданных денег четыреста тридцать три рубли сорок 
четыре копейки с полтиною, прося о возвращении ему тех из пограничной суммы» (РГАДА, ф. 16, оп. 1, д. 991, ч. 1, л. 257 об. 258).

Пресловутый же «росход денгам» казны в поездке - на дорожные расходы, «на подарки шести старшинам» и на подарки «разные мелочные», «на трактамент киргизцам разные случаи», судя по росписи в бумагах губернатора, составил, помимо долга, допущенного муфтием, 819 руб. 46 коп. (РГАДА, ф. 16 , оп. 1, д. 991, ч. 1, л. 258).

Выраженная весной 1790 г. во время степного вояжа настойчивость муфтия в самовольном и явно сверх полномочий представительстве от лица верховной власти перед степняками исключала его случайную ошибку. Об этом же говорили и жалобы духовенства. Из которых вытекало, что глава ОМДС желал посредничать между казахами и властями без участия кого бы то ни было со стороны и только лично, а муллам, служившим в Оренбургской Пограничных дел экспедиции и Уральском войске, угрожал:

«Тех мулл, которые о происходящих между народа киргизского делах здешнего края начальников уведомляют (без позволения муфтия. - А.Р.), зделаю я яко скотов» (РГАДА, ф. 16, оп. 1, д. 991, ч. 1, л. 254 об.).

Почву для подобных доносов во многом подготовил сам муфтий. Будучи человеком умным, деловитым, и, по отзыву современников, дипломатичным, во взаимоотношениях с мусульманским духовенством, особенно служащими Оренбургской Пограничных дел экспедиции и Уральского войска, он раскрывался с неожиданной стороны - оказывался самовлюблённым деспотом. Как следствие, муллы искали содействия у русских светских властей, и сведения об этих поисках доходили до губернатора, упрочивая предубеждение против муфтия и результатов его работы в степи.

«Однако ж полагаю, - обращался в итоге А.А. Пеутлинг к Екатерине II, - что он сие учинил более от незнания по иностранству ево законов Империи Вашей и по не доволно просвещенной ревности в чаянии, что делает все к лучшему...» (РГАДА, ф. 16, оп. 1, д. 991, ч. 1, л. 258).

Причины сдержанности А.А. Пеутлинга в данном случае понятны: муфтий имел заслуги перед властями, в своё время был принят монархиней, она, особенно в связи с письмами Мансура, придавала большое значение успеху весенних переговоров в Степи и той агитационной работы, которую муфтию надлежало вести среди казахов с началом русско-турецкой войны. Однако недовольство сановника подпитывалось сведениями о «непозволительной переписке» Срыма с Бухарой и посланиях, поступавших оттуда и адресованных как ему, так и другим, близким к нему казахским старшинам. Тексты в феврале того же года русским властям передал мулла Г. Искендеров - доверенный человек губернатора. Судя по содержанию, они исходили из кругов среднеазиатского духовенства, несли призывы к мусульманской солидарности и, соответственно, к войне против христианской России (РГАДА, ф. 16, оп. 1, 
д. 991, ч. 2, л. 22; ч. 3, л. 66). Не придавать значения подобным сообщениям, совершенно обесценивавшим результаты весенней поездки, заявленные муфтием, губернатор не мог.

Муфтию подобные претензии были не в новинку: он сталкивался с ними в 1788 г., когда полковник Д.А. Гранкин выражал недовольство после организованной муфтием присяги степняков. Тогда лишь вмешательство губернатора О.А. Игельстрома остановило дело (Казахско-русские отношения в XVIII-XIX веках, 1964, с. 126; Материалы по истории Казахской ССР, 1940, с. 104-106, 109, 113, 119, 120). Ныне же, несмотря на отсутствие прежнего покровителя, муфтий полагал свои позиции более прочными, вполне освоившись с ролью «мусульманского министра» Екатерины II, и даже начал свою интригу против губернатора.

Стоит отметить поразительную уверенность муфтия в затеянном деле. Она ещё более обращает на себя внимание при сравнении поведения М. Хусейнова и первого крымского муфтия, которым тогда был Мусалар эфенди, назначенный в 1784 г.: нося на себе клеймо неблагонадёжного, тот был в полной зависимости от российских властей (Прохоров, 2020, с. 181), тогда как М. Хусейнов, не вызывавший сомнений в своей лояльности, как видим, буквально выгрызал собственное «пространство свободы» безо всякой оглядки на инстанции. Ни один крымский муфтий себе такого позволить не мог и позже, да и в Оренбургском собрании преемники М. Хусейнова вели себя куда скромнее.

О том, как развивалась муфтиева интрига, А.А. Пеутлинг сообщал А.А. Безбородко в донесении от 19 февраля 1791 г. (РГАДА, ф. 16, оп. 1, д. 991, ч. 1, л. 254 об., 255). В документе речь шла об очередном доносе на муфтия. Его составил заседатель Оренбургского пограничного суда Нурмухаммед Ходжа, зять хана Нурали. Он сообщал, что во время поездки в степь узнал о сговоре муфтия и Срыма, который заключался в том, чтоб обоим жаловаться императрице на губернатора «Александра Александровича» и атамана-уральца полковника Денисова, «что сии два человека наше общество довели до последнего состояния, да и он, муфтий не оставит, чтоб их не лишить мест», и до тех пор не успокоится (РГАДА, ф. 16, оп. 1, д. 991, ч. 3, л. 76). Такая жалоба, продолжал заседатель, якобы послана из Оренбурга в столицу, и муфтий бахвалился, что уверен в успехе: если даже бумагу перехватят на почте и не доведут до монархини, «то я сам к Её Величеству донести имею...» (РГАДА, ф. 16, оп. 1, д. 991, ч. 3, л.76 об.).

«Муфтий против доверенности Е.И. В-ва и присяжной ево должности изменяет несоответственное», он явно нарушил те политически принципы, которые проводит губернатор и которые он как духовное лицо на русской службе обязан защищать, «...и в том писме ничего иного кроме к разврату и нарушению в народе спокойствия не предвидимо...», - резюмировал Нурмухаммед Ходжа (РГАДА, ф. 16, оп. 1, д. 991, ч. 3, л.76 и об.). 
Однако интрига муфтия против губернатора, как вытекало из объяснений последнего, направленных А.А. Безбородко, этим не исчерпывалась:

«...На сих днях... представлено ко мне донесение верного старшины Базарбая о сих муфтиевых внушениях... При том же он, муфтий, разным людям старается внушать, якобы я подвержен гневу Е.И. В-ва, в скором времени буду отрешен от должности, в чем он старался при отъезде Нурмухаммет Ходжи и ево уверить, что он при возвращении его из Орды, конечно, меня уже здесь (в Уфе - А.Р.) не найдет...» (РГАДА, ф. 16, оп. 1, д. 991, ч. 3, л. 67 об.).

Положение сановника оказывалось предельно сложным. Не давать хода подобным сведениям он не мог, но конфликтовать с муфтием открыто означало бы нажить врага и в лице О.А. Игельстрома, человеком которого считался муфтий и который номинально оставался наместником. Ощущая неустойчивость и даже двусмысленность своего положения, А.А. Пеутлинг обратился напрямую к покровителю муфтия: оригинал доноса Нурмухаммеда Ходжи он послал именно О.А. Игельстрому. Копия бумаги ушла А.А. Безбородко с обещанием присылки других оригиналов муфтиевых бумаг после новой поездки агента губернатора в Степь (РГАДА, ф. 16, оп. 1, д. 991, ч. 3, л. 66 об.).

В обоих случаях губернатор резюмировал: муфтий пытался убедить степняков в непрочности позиций А.А. Пеутлинга, склонить их к непослушанию ему и тем самым скомпрометировать губернатора перед столицей. В этой связи губернатор и апеллировал к А.А. Безбородко, указывая, что муфтий не останавливается ни перед чем, организуя против губернатора саботаж:

«...Он, муфтий..., ища таковыми ухищренными внушениями довести до того, чтоб по поручениям моим не было рачительного исполнения, и я бы, не взирая на все усерднейшие мои старания, не мог иметь успеха об успокоении Орды и в приведении оной по возможности в лутчее свойство, то и почел непременно доложить о сих зловредных его, муфтия, поступках [и] всепокорнейшее представить на прозорливое рассмотрение Вашего Сиятельства, испрашивая себе великодушного Вашего покровительства и защищения» (РГАДА, ф. 16, оп. 1, д. 991, ч. 3 , л. 67 об.).

До Ясского мирного договора, завершившего длившуюся на тот момент турецкую войну, было еще далеко (его подписали только 29 декабря 1791 г.), и постоянные известия о том, что Срым склонен поддаваться враждебным увещеваниям и надеется на прямую помощь из Бухары, губернатор не мог воспринимать индифферентно: получалось, что угроза «борьбы за веру» под главенством Срыма сохраняется, пусть и не из-за писем Мансура. В контексте происходившего наместник указывал на пользу того, чтобы прервать отношения Младшего жуза с Бухарой, в частности, исключить посылку детей казахской знати и старшин в Бухару с образовательной целью (РГАДА, ф. 16, оп. 1, д. 991, ч. 3, л. 2).

Среди потока сообщений губернатор летом - осенью 1791 г. по-прежнему выделял сведения о союзе Османской империи и Бухары, имевшие под собой действительные основания (Васильев, 2014, с. 109, 110), что делало противодей- 
ствие бухарским призывам к войне, адресованным Срыму и близким ему людям, еще более актуальным (РГАДА, ф. 16, оп. 1, д. 991, ч. 3, л. 22). В итоге губернатор оказывался в тупиковой ситуации: нуждаясь в муфтии как проводнике российской линии в делах ислама и казахов, он не доверял ему и опасался давать ответственные поручения.

\section{Финал противостояния}

А.А. Безбородко понимал, что замены или удаления муфтия ожидать не приходится, старался оказать сановнику помощь. Его усилиями 24 декабря 1791 г. вышел указ о вызове муфтия в Петербург по повелению Екатерины II (РГАДА, ф. 16, оп. 1, д. 991, ч. 3, л. 148). В столице М. Хусейнов был награждён за успех степной поездки 1790 г. Екатерина II, несмотря на сведения, поступавшие после неё, всё же сочла результат муфтиева визита успешным, ибо до декабря 1790 г., когда пал Измаил и победа в войне окончательно определилась, выступлений кочевников на юго-восточной границе не было, и в этом, полагала императрица, состояла явная неудача организаторов интриги с посланиями шейха (Ряжев, 2004, с. 53).

Тем не менее муфтий получил установку впредь держаться в отношении губернатора предельно лояльно. С подачи А.А. Безбородко вскоре Екатерина II положила конец прекарному состоянию А.А. Пеутлинга: в 1792 г. он был утверждён на посту наместника. Однако отношения губернатора и муфтия остались враждебными, начинания губернатора особого успеха не имели, и в ноябре 1794 г. последовала его отставка. В конечном итоге Екатерине II пришлось вернуть на юго-восток О.А. Игельстрома, продолжившего свою работу в новых условиях.

Причины подобного исхода конфликта, на первый взгляд, очевидны, и о них уже было сказано: в делах религии, особенно в связи с российскотурецким противостоянием муфтий оказывался для верховной власти более важной фигурой, нежели губернатор.

Вместе с тем отставка А.А. Пеутлинга означала, что потерпел неудачу замысел урегулирования пограничной ситуации, который он вынашивал. Помимо противостояния с муфтием, имело место и несхождение мнений губернатора и российских нижестоящих пограничных властей, военных командиров. В частности, и Я.М. Зембулатов, начальник Оренбургской Пограничных дел экспедиции, и атаман Д.Д. Донсков, проведя годы на границе, проникнувшись жестокими неписанными правилами степной войны, мастерами которой были и казахи, ожидали того же от наместника. По этому поводу Пеутлинг объяснялся с Екатериной II: «Я вижу себя наконец принужденным Вашему Императорскому Величеству признаться, что со вступления моего во Всевысочайше мне вверенный долг управления здешними пограничными делами зделано мне было от оной Експедиции всегда весма строптиво... 
послушание, привязан[ной] будучи к суровой той мысли, что с киргизцами поступать должно по азиатскому обычаю, то есть грабить и разорять...» (РГАДА, ф. 16, оп. 1, д. 991, ч. 1, л. 323 об., 324).

По Пеутлингу же пограничное урегулирование должно было носить исключительно правовой, бюрократический характер, когда конфликтующим сторонам отводилась роль пассивных исполнителей новых законов, способных удержать их от столкновений и нарушений.

В этом плане ближе к жизни оказывался О.А. Игельстром, настаивавший не только на сугубо правовых мерах, но, прежде всего, на последовательной интеграции казахского общества в систему российских порядков, упиравший на человеческий фактор данного процесса - формирование прослойки светских посредников в казахской среде, способных действовать в российских видах, получать взамен осязаемую материальную и социальную выгоду.

\section{Заключение}

Зависимость муфтиев от губернаторов давно стала общим местом историографии. Изученный эпизод демонстрирует, что в обстановке фронтира, в условиях, когда имперская политика в отношении мусульман переживала становление, находилось место иным сценариям взаимоотношений светских властей и мусульманских институций. Разумеется, свою роль в обозначенных событиях в полной мере сыграл субъективный, личностный фактор. Но сказалась и специфика пограничной ситуации на российском юго-востоке по сравнению с тогдашним Крымом и более поздним, первой трети XIX в., Северным Кавказом.

\section{Благодарности}

Исследование проведено в рамках государственной субсидии - проект «Комплексное исследование процессов общественно-политического и культурного развития народов Юга России» (номер госрегистрации: AAAA-A19119011490038-5).

\section{Список литературы}

Campbell, I. W. (2017). Knowledge and the ends of Empire: Kazak intermediaries and Russian rule on the steppe, 1731-1917. Cornell University Press. https://doi.org/10.7591/9781501707902

Азаматов, Д. Д. (1999). Оренбургское магометанское духовное собрание в конце XVIII-XIX вв. Гилем.

Васильев, А. Д. (2014). «Знамя и меч от падишаха». Политические и культурные контакты ханств Центральной Азии и Османской илперии (середина XVI - начало XX вв.).

Институт востоковедения РАН, ПРОБЕЛ-2000. 
Вяткин, М. П. (1939). Журнал оренбургского муфтия. Исторический архив, 2, 118-221.

Вяткин, М. П. (1947). Батыр Срым (Освободительное движение в Казахстане в конще XVIII в.). Издательство АН СССР.

Горбунова, С. В. (2008). Государственная регламентация религиозной жизни казахов в Российской империи. Вестник Нижневартовского государственного гуманитарного университета, 1, 35-41.

Елисеева, О. И. (2005). Григорий Потемкин. Молодая гвардия.

Избасарова, Г. Б. (2015). Принципы функционирования властной элиты Степи в политической организации Российской империи (на примере службы султана Ахмета Джантюрина). Вестник Московского университета. Серия 8: История, 5-6, 64-79.

История Казахской ССР (с древнейших времен до наших дней) (Т. 3). (1979). Наука КазССР.

Казахско-русские отношения в XVIII-XIX веках (1771-1876 годы) (Сборник документов и материалов). (1964). Наука.

Ковальская, С. И., \& Любичанковский, С. В. (2017). Религиозная политика Российской империи в казахской степи в период XVIII-XIX веков. Университетский научный журнал: филологические и исторические науки, археология и искусствоведение, 33, 18-32.

Конкин, Д. В. (2020). Шейх Мансур и его последователи в Крыму (конец XVIII в.). В Исторические, культурные, межнациональные, религиозные и политические связи Крыма со средиземноморским регионом и странами Востока. IV международная научная конференция (Севастополь, 6-10 октября 2020 г.). Материалы конференции (Т. 2, сс. 134-138). Институт востоковедения РАН.

Лапин, Н. С. (2012). Деятельность О. А. Игельстрома в контексте казахско-российских взаимоотношений (1780 - 1790-е годы). Издательство «Сарыарка».

Лысенко, Ю. А. (2010). «Татарский вопрос» в конфессиональной политике Российской империи в Казахстане (конец XVIII - начало XX в.). Известия Алтайского государственного университета, 4-3, 146-152.

Любичанковский, С. В. (2016). Поддержка ислама среди казахов как государственная политика дореформенной России (XVIII - середина XIX вв.). В Кадырбаевские чтения 2016: Материалы V международной научной конференции (сс. 74-79). б.и.

Материалы по истории Казахской ССР. (1785-1828 г2.) (Т. 4). (1940). Издательство АН СССР.

Материалы по истории политического строя Казахстана (со времени присоединения Казахстана к России до Великой Октябрьской сощиалистической револющии) (Т. 1). (1960). Издательство Академии наук КазССР.

Махмутов, 3. А. (2017). Духовная и образовательная деятельность татар в казахской Степи в контексте внутренней политики Российской империи (вторая половина XVIII - начало XX века). Самарский научный вестник, 6(1), 113-117.

Мубаракзянов, М. А. (2011). Политика российского правительства в отношении Малого жуза в 80-90-е гг. XVIII в. и оренбургский муфтий М. Хусаинов. В Оренбургское магометанское духовное собрание и духовное развитие татарского народа в последней четверти XVIII - начале XX вв.: Материалы одноименного научного семинара, посвященного 220-летию учреждения религиозного управления мусульман внутренней России и Сибири (Казань, 18 декабря 2009 г.) (сс. 100-107). Институт истории им. Ш. Марджани Академии наук Республики Татарстан. 
Почекаев, Р. Ю. (2014). Религиозная политика российской имперской администрации в Центральной Азии как фактор фронтирной модернизации: От О. А. Игельстрома до К. П. фон Кауфмана. В Религия в истории народов России и Центральной Азии: Материалы II международной научной конференции. Барнаул, 29 октября - 1 ноября 2014 г. (сс. 247-252). Издательство Алтайского университета.

Проблемы интегращии Крыма в состав России, 1783-1825. (2017). Альбатрос.

Прохоров, Д. А. (2020). Этноконфессиональные общины. В Российская империя и Крым (сс. 165-215). Издательский дом Крымского федерального университета.

Ремнёв, А. В. (2006). Татары в казахской степи: Соратники и соперники Российской империи. Вестник Евразии, 4, 5-32.

Речкина, И. А. (2006). Мусульманская политика российских властей в казахской степи (конец XVIII в. - 60-е гг. XIX в.). Вестник Омского университета, 2, 80-84.

Российский государственный архив древних актов. (б. д.). Ф. 16. Оп. 1. Д. 991. Ч. 1-4.

Ряжев, А. С. (2004). Просвещенное духовенство при Екатерине II. Bопросы истории, 9, 43-57.

Ряжев, А. С. (2006). Вероисповедная политика русского «просвещенного абсолютизма»: История изучения. В История и историки: Историографический вестник (сс. 84-126). Наука.

Ряжев, А. С. (2020). Мираж религиозной войны: Обстановка на юго-востоке Российской империи в оценках пограничных властей (конец 1780 - начало 1790-х гг.). В Центральная Азия на перекрестке европейских и азиатских политических интересов: XVIII-XIX вв. Сборник научных трудов (сс. 100-112). ОнтоПринт.

Смирнов, Н. А. (1950). Шейх Мансур и его турецкие вдохновители. Вопросы истории, $10,15-24$.

Султангалиева, Г. С. (2009). Казахское чиновничества Оренбургского ведомства: Формирование и направление деятельности (XIX в.). Acta Slavica Iaponica, 27, 77-101.

Султангалиева, Г. С. (2011). Деятельность первого оренбургского муфтия Мухамеджана Хусаинова в Казахской степи. В Оренбургское магометанское духовное собрание и духовное развитие татарского народа в последней четверти XVIII - начале XX вв.: Материалы одноиленного научного семинара, посвященного 220-летию учреждения религиозного управления мусульман внутренней России и Сибири (Казань, 18 декабря 2009 2.). Институт истории им. Ш. Марджани Академии наук Республики Татарстан.

Султангалиева, Г. С. (2012). Первый муфтий оренбургского мусульманского собрания Мухамеджан Хусаинов и казахские старшины. ҚазҰУ хабаршысы. Тарих сериясы (Вестник КазНУ. Серия Историческая), 1, 35-39.

Франк, А. (1993). Татарские муллы среди казахов и киргизов в XVIII-XIX веках. В Культура, искусство татарского народа: Истоки, традиции, взаимосвязи (сс. 124-132). Институт языка, литературы и истории им. Г. Ибрагимова Академии наук Республики Татарстан.

Хайрединова, 3. 3. (2016). Роль первых таврических муфтиев и проблемы интеграции мусульманского населения Крыма в состав России (1783-1830 гг.). Вестник Кемеровского государственного университета, 1, 66-71.

Шаблей, П. С. (2008). Оренбургское магометанское духовное собрание в Казахстане (1788-1868 гг.). Вопросы истории, 5, 146-150. 
Журнал Фронтирных Исследований. 2022. No 1 | ISSN: 2500-0225

Имперские практики | https://doi.org/10.46539/jfs.v7i1.378

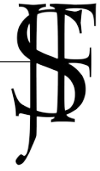

Шаблей, П. С. (2010). Социальный облик мусульманских служащих в Казахской степи (конец XVIII-середина XIX в.). Pax Islamica, 2, 91-107.

\section{References}

Azamatov, D. D. (1999). The Orenburg Mohammedan Spiritual Assembly in the late 18th and $19^{\text {th }}$ centuries. Gilem. (In Russian).

Campbell, I. W. (2017). Knowledge and the ends of Empire: Kazak intermediaries and Russian rule on the steppe, 1731-1917. Cornell University Press. https://doi.org/10.7591/9781501707902

Eliseeva, O. I. (2005). Grigory Potemkin. Young Guard. (In Russian).

Frank, A. (1993). Tatar mullahs among the Kazakhs and Kyrgyz in the 18th and 19th centuries. In Culture, Art of the Tatar People: Origins, Traditions, Interrelationships (pp. 124-132). The G. Ibragimov Institute of Language, Literature and History of the Academy of Sciences of the Republic of Tatarstan. (In Russian).

Gorbunova, S. V. (2008). State regulation of the religious life of the Kazakhs in the Russian Empire. Bulletin of the Nizhnevartovsk State Humanitarian University, 1, 35-41. (In Russian).

History of the Kazakh SSR (from ancient times to the present) (Vol. 3). (1979). Nauka Kazakh SSR. (In Russian).

Izbasarova, G. B. (2015). Principles of functioning of the power elite of the Steppe in the political organization of the Russian Empire (on the example of the service of Sultan Ahmet Dzhanturin). Bulletin of Moscow University. Series 8: History, 5-6, 64-79. (In Russian).

Kazakh-Russian relations in the 18th-19th centuries (1771-1876) (Collection of documents and materials). (1964). Nauka. (In Russian).

Khairedinova, Z. Z. (2016). The Role of the First Muftis of Tauris and the Problems of Integration of the Muslim Population of Crimea into Russia (1783-1830). Bulletin of Kemerovo State University, 1, 66-71. (In Russian).

Konkin, D. V. (2020). Sheikh Mansur and his followers in the Crimea (late 18th century). In Historical, cultural, interethnic, religious and political ties of Crimea with the Mediterranean region and the countries of the East. IV International Scientific Conference (Sevastopol, October 6-10, 2020). Conference materials (Vol. 2, pp. 134-138). Institute of Oriental Studies, Russian Academy of Sciences. (In Russian).

Kovalskaya, S. I., \& Lubichankovsky, S. V. (2017). The Religious Policy of the Russian Empire in the Kazakh Steppe in the 18th-19th Centuries. University Journal of Science: Philological and Historical Sciences, Archaeology and Art History, 33, 18-32. (In Russian).

Lapin, N. S. (2012). O.A. Igelstrom's activities in the context of Kazakh-Russian relations (1780s - 1790s). Saryarka Publishers. (In Russian).

Lubichankovsky, S. V. (2016). Promoting Islam among the Kazakhs as a state policy in pre-reform Russia (18th - mid 19th centuries). In Kadyrbayev Readings - 2016: Proceedings of the V International Scientific Conference (pp. 74-79). n.p. (In Russian). 
Lysenko, Y. A. (2010). The "Tatar question" in the confessional policy of the Russian Empire in Kazakhstan (late 18th - early 20th centuries). Izvestia of Altai State University, 4-3, 146-152. (In Russian).

Makhmutov, Z. A. (2017). Spiritual and educational activities of the Tatars in the Kazakh Steppe in the context of the Russian Empire's domestic policy (second half of the 18th century - early 20th century). Samara Scientific Bulletin, 6(1), 113-117. (In Russian).

Mubarakzyanov, M. A. (2011). Russian government policy towards the Minor Juz in the 1980s-90s and the Orenburg Mufti M. Khusainov. In Orenburg Mohammedan Spiritual Assembly and Spiritual Development of Tatar People in the Last Quarter of the 18th - Early 20th Centuries: Materials of the Scientific Seminar of the same name, dedicated to the 220th anniversary of the foundation of Muslim religious board of inner Russia and Siberia (Kazan, December 18, 2009). (pp. 100-107). The Sh. Marjani Institute of History, Academy of Sciences of the Republic of Tatarstan. (In Russian).

Pochekaev, R. Yu. (2014). The Religious Policy of the Russian Imperial Administration in Central Asia as a Factor of Frontier Modernization: From O. A. Igelstrom to K. P. von Kaufmann. In Religion in the History of the Peoples of Russia and Central Asia: Proceedings of the II International Scientific Conference. Barnaul, 29 October - 1 November 2014. (pp. 247-252). Altai University Press. (In Russian).

Problems of integrating Crimea into Russia, 1783-1825. (2017). Albatros. (In Russian).

Proceedings of the History of the Kazakh SSR. (1785-1828). (Vol. 4). (1940). USSR Academy of Sciences Publishing. (In Russian).

Proceedings on the History of the Political System of Kazakhstan (from the Accession of Kazakhstan to Russia to the Great October Socialist Revolution) (Vol. 1). (1960). Publishing house of the Academy of Sciences of the Kazakh SSR. (In Russian).

Prokhorov, D. A. (2020). Ethno-confessional communities. In The Russian Empire and the Crimea (pp. 165-215). Crimean Federal University Publishing House. (In Russian).

Rechkina, I. A. (2006). The Muslim policy of the Russian authorities in the Kazakh steppe (late $18^{\text {th }}$ century - 1860s). Bulletin of Omsk University, 2, 80-84. (In Russian).

Remnyov, A. V. (2006). Tatars in the Kazakh Steppe: Supporters and rivals of the Russian Empire. Eurasia Herald, 4, 5-32. (In Russian).

Russian State Archive of Ancient Documents. (n. d.). F. 16. In. 1. C. 991. Parts 1-4. (In Russian).

Ryazhev, A. S. (2004). Enlightened clergy under Catherine II. Historical issues, 9, 43-57. (In Russian).

Ryazhev, A. S. (2006). The religious policy of Russian "Enlightened Absolutism": a history of study. In History and Historians: a Historiographic Messenger (pp. 84-126). Nauka. (In Russian).

Ryazhev, A. S. (2020). The Mirage of Religious War: The Situation in the South-East of the Russian Empire as Viewed by Border Authorities (late 1780s - early 1790s). In Central Asia at the Crossroads of European and Asian Political Interests: Eighteenth and Nineteenth Centuries. Collection of research papers (pp. 100-112). OntoPrint. (In Russian).

Shabley, P. S. (2008). Orenburg Mohammedan Spiritual Assembly in Kazakhstan (1788-1868). Historical issues, 5, 146-150. (In Russian). 
Shabley, P. S. (2010). The Social Appearance of Muslim Servants in the Kazakh Steppe (late 18th mid 19th centuries). Pax Islamica, 2, 91-107. (In Russian).

Smirnov, N. A. (1950). Sheikh Mansour and his Turkish masterminds. Historical issues, 10, 15-24. (In Russian).

Sultangalieva, G. S. (2009). Kazakh officialdom in the Orenburg department: Formation and direction of activity (19th century). Acta Slavica Iaponica, 27, 77-101. (In Russian).

Sultangalieva, G. S. (2011). Activities of the first Mufti of Orenburg, Mukhamedzhan Husainov, in the Kazakh steppe. In Orenburg Mohammedan Spiritual Assembly and Spiritual Development of Tatar People in the Last Quarter of the 18th - Early 20th Centuries: Materials of the Scientific Seminar of the same name, dedicated to the 220th anniversary of the foundation of Muslim religious board of inner Russia and Siberia (Kazan, December 18, 2009). The Sh. Marjani Institute of History, Academy of Sciences of the Republic of Tatarstan. (In Russian).

Sultangalieva, G. S. (2012). The first Mufti of the Orenburg Muslim Assembly, Muhamedjan Husainov, and Kazakh elders. Bulletin of KazSU. Series Historical, 1, 35-39. (In Russian).

Vasiliev, A. D. (2014). "The Banner and Sword from the Padishah". Political and cultural contacts between the khanates of Central Asia and the Ottoman Empire (mid-16th to early 20th centuries). Institute of Oriental Studies, Russian Academy of Sciences, PROBEL-2000. (In Russian).

Vyatkin, M. P. (1939). Journal of the Orenburg Mufti. Historical Archive, 2, 118-221.

Vyatkin, M. P. (1947). Batyr Srym (The liberation movement in Kazakhstan at the end of the $18^{\text {th }}$ century). USSR Academy of Sciences Publishing. (In Russian). 